$\begin{array}{r}\text { Contents lists available at BIOSFER } \\ \text { BIOSFER: JURNAL TADRIS BIOLOGI } \\ \text { p-ISSN: 2086-5945 (print), e-ISSN: 2580-4960 (online), DOI 10.24042/biosphere } \\ \text { http://ejournal.radenintan.ac.id/index.php/biosfer/index } \\ \hline \hline\end{array}$

\title{
Internalization of Religious Values Using the Argument-Driven Inquiry Model to Improve Critical Thinking Skills during the COVID-19 Pandemic
}

\author{
Yeyen Siti Fitriani ${ }^{*}$, Anda Juanda ${ }^{2}$, Evi Roviati ${ }^{3}$ \\ 1, 2, 3 Tadris Biology, FITK, IAIN Syekh Nurjati Cirebon, Indonesia
}

\begin{abstract}
ARTICLE INFO
Article History

Received : 23-10-2020

Accepted : 23-11-2020

Published : 31-12-2020

Keywords:

Internalization of religious values;

Argument-driven Inquiry Model;

Critical thinking skills.

*Correspondence Address: yeyensitifitriani@gmail.com

ABSTRACT

This research aimed to describe students' activities, the improvement differences of students' critical thinking skills, and explain students' responses toward the internalization of religious values using the Argument-Driven Inquiry model on reproductive system material at eleventh-grade students of MAN 1 Kuningan. The method used in this research was the quantitative method with the experimental pretestposttest control group design. This research population was all eleventhgrade students of MAN 1 Kuningan, which consisted of eight classes, five science classes, and three social studies classes. The research sample was taken using a random sampling technique. This research sample was class XI IPA 1 as the experimental class (35 students) and XI IPA 3 as the control class (34 students). The data collection techniques employed were observation, tests, and questionnaires. The data was analyzed using SPSS v.25 software. The results obtained showed that the highest learning activity was at the data collection stage. There was an improvement in students' critical thinking skills in the experimental class and the control class. The average $\mathrm{N}$-Gain of the experimental class was 0.69 , and the control class was 0.33 . The sig statistical test results were $0.000<0.655$, meaning that $\mathrm{H}_{0}$ was rejected and $\mathrm{H}_{a}$ was accepted. Thus, there was a significant improvement in students' critical thinking skills between the experimental and control classes.
\end{abstract}

\section{Internalisasi Nilai-nilai Religius Menggunakan Model Argument Driven Inquiry Untuk Meningkatkan Keterampilan Berpikir Kritis di Masa Pandemi Covid-19}

Abstrak: Tujuan dari penelitian adalah mendeskripsikan aktivitas siswa;
menganalisis perbedaan peningkatan keterampilan berpikir kritis siswa;
dan menjelaskan respon siswa terhadap internalisasi nilai-nilai religius
menggunakan model Argument Driven Inquiry pada materi sistem
reproduksi untuk meningkatkan keterampilan berpikir kritis siswa.
Metode yang digunakan dalam penelitian ini adalah metode kuantitatif
yang bersifat eksperimen dengan desain penelitian pretest posttest control
design group. Teknik pengumpulan data dalam penelitian ini adalah
observasi, tes dan angket. Analisis data menggunakan software SPSS v.25. 
Biosfer, 11 (2) (2020) 139 - 150

Yeyen Siti Fitriani, Anda Juanda, Evi Roviati

terdiri dari uji prasyarat dan uji beda. Hasil yang diperoleh aktivitas
belajar siswa menunjukkan aktivitas belajar tertinggi pada tahap
pengumpulan data; terdapat perbedaan peningkatan keterampilan
berpikir kritis siswa kelas eksperimen dan kontrol meningkat dengan rata-
rata $\mathrm{N}$-Gain kelas eksperimen 0,69 dan kontrol 0,33 dan hasil uji statistik
sig. 0,000 < 0,655, artinya H0 ditolak dan Ha diterima, sehingga terdapat
perbedaan peningkatan keterampilan berpikir kritis siswa yang signifikan
antara kelas eksperimen dengan kelas control; angket respon siswa
terhadap penerapan internalisasi nilai-nilai religius menggunakan model
Argument Driven Inquiry menunjukkan 57\% dengan kriteria sangat kuat
dan 43\% dengan kriteria kuat, sehingga pembelajaran dapat diterima
dengan baik oleh siswa.

\section{INTRODUCTION}

Education is a fundamental thing that must be possessed by every individual (Bangun, 2016; Saat, 2015; Wahyuni et al., 2013). Education is not only aimed at gaining knowledge for young generations (Brata \& Sudirga, 2019; Irhandayaningsih, 2013) but also aims to obtain individuals who have noble character and skills as to live in a society (Romdoni \& Malihah, 2020; Setiardi \& Mubarok, 2017; Shawmi, 2015). Education is closely related to the students' learning process. Learning is a process of changing behavior due to education experiences (Aditya, 2016; Asrori, 2013; Aziz, 2012).

Dewi et al. (2015) state that learning in schools in modern times emphasizes disciplines with strict specialization without integration between disciplines and religious sciences. The process of internalizing religious values is fundamental in learning biology in everyday life, be it in the school, family, and community environment (Azhar \& Sa'idah, 2017; Mumin, 2018; Muspiroh, 2016; Sofanudin, 2015). The internalization of religious values in biology learning needs to be done so that students can understand religious values related to problems in everyday life, especially the reproductive system material (Bahri, 2015; Hanif et al., 2016; Okmarisa et al., 2016) so that it affects good morals and can stay away from what is prohibited by religion (Ginanjar, 2017; Juraini et al., 2018). Adolescents must know their sexual organs' function and dangerous venereal diseases through education, especially in schools, by integrating character values (Fauziah, 2018; Rachmayanie, 2017). Someone who has a religious character can be a good person (Cahyono, 2016; Kautsar \& Edi, 2017; Khotimah, 2016; Syafe'i, 2017).

Learning by internalizing religious values is also attempted to train students' critical thinking skills to understand the concept of the material they learn in everyday life (Hanif et al., 2016; Rosyad, 2019; Widyaningsih et al., 2014). Learning that involves students directly, especially in mental activities, is one of the factors that can encourage someone to think critically (Adnyana, 2012).

Critical thinking skills in the learning process can train students to carefully, thoroughly, and logically decide based on various points of view (Nisa et al., 2019; Zubaidah, 2010). By thinking critically, students are expected to show the superiority of information, correct themselves, and examine the various gifts and pleasures they receive from Allah (Husna Nafila et al., 2016). Increasing critical thinking skills requires a stimulating learning environment and atmosphere (Husamah et al., 2017; Lestari et al., 2016; Novrizawati et al., 2017). Based on this explanation, critical thinking skills need to be empowered or stimulated. This habituation or stimulus cannot be carried out in conventional atmospheres, strategies, and learning models. Therefore, 
it requires systematic efforts as an alternative through the application of the Argument-Driven Inquiry learning model. Argumentation-based science learning activities will encourage students to develop thinking skills and habits (Nafi'ah \& Prasetyo, 2015; Rustaman, 2011).

Previous research regarding the Argument-Driven Inquiry learning model has been carried out on the ability to think and argue (Hidayat, 2017; Marhamah et al., 2017). Widyaningsih et al. (2014) conducted a study on the internalization of religious values based on junior high school students' phenomenological perspective. Thus, there has never been any research that specifically examines the internalization of religious values using the Argument-Driven Inquiry model and critical thinking skills. Regarding critical thinking skills, several previous studies have been carried out, including the impact of using a station learning model (Abdurrohman \& Djuniadi, 2016), cycle 7E model(Adnyani et al., 2018), and the discovery learning model (Haeruman et al., 2017). Based on the background, it is necessary to conduct research that examines the internalization of religious values, the Argument-Driven Inquiry model, and critical thinking skills. The purpose of this research was to describe students' activities, analyze improvement differences in students' critical thinking skills, and explain students' responses to the internalization of religious values using the Argument-Driven Inquiry model on reproductive system material.

\section{METHOD}

The method used in this research was the quantitative method of experimental research with the pretest-posttest control group design. This research was conducted at MAN 1 Kuningan. The research sample was taken using a random sampling technique. The samples consisted of two classes, the experimental class, and the control class. The research data were collected through observation, tests, and questionnaires. The observations were made using the observation sheet and learning assessment rubric developed based on the syntax of the ArgumentDriven Inquiry model and the indicators of students' critical thinking skills aimed to measure student activity in the learning process. The data were analyzed using SPSS v.25 software, which consisted of a prerequisite test and an independent sample t-test.

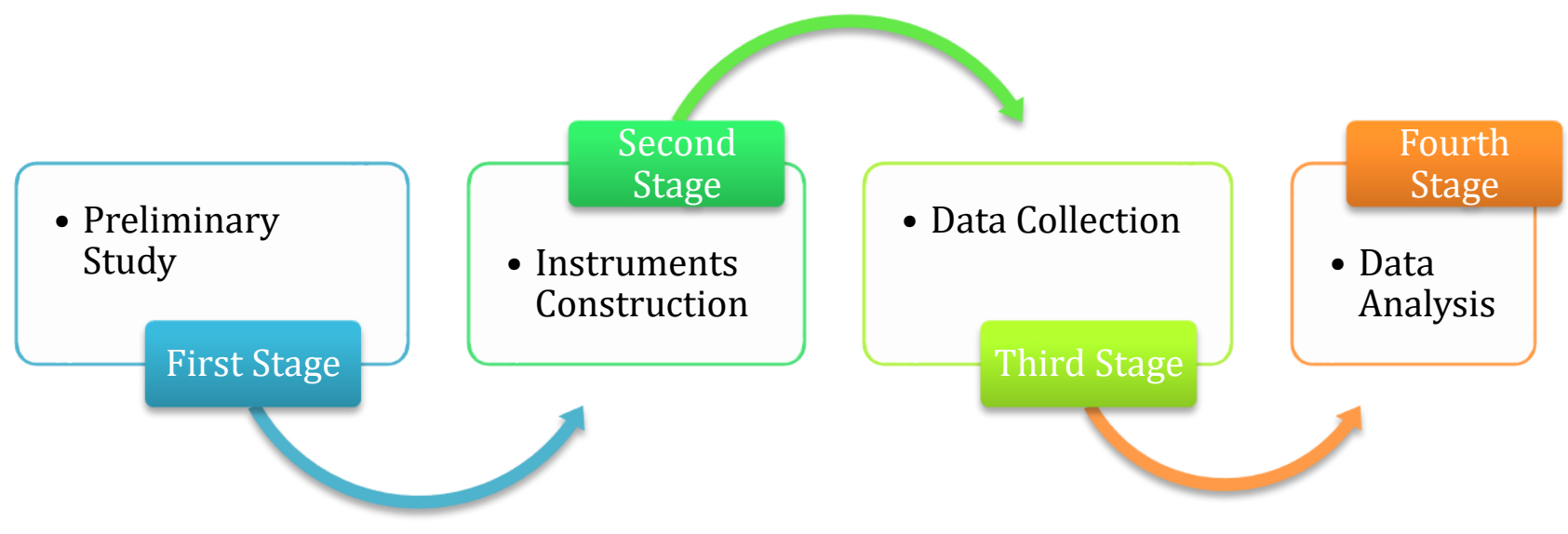

Figure 1. Research Data Analysis Techniques 
As the treatment, the research carried out online learning due to the COVID-19 pandemic situation, which requires students to learn remotely using online learning applications. Researchers' application to support the online learning process was the WhatsApp application that uses WAG (WhatsApp Group) to carry out discussions in the learning process.

\section{RESULTS AND DISCUSSION}

The results obtained in this research consisted of students' activity during the internalization of religious values using the Argument-Driven Inquiry Model and the improvement differences of critical thinking skills between the experimental class and the control class. The following are the results of research conducted at MAN 1 Kuningan.

Students' activities in learning were observed through observation. Figure 1 displays the average value of students' activity in the experimental class at each meeting.

The Average Value of Students' Activity

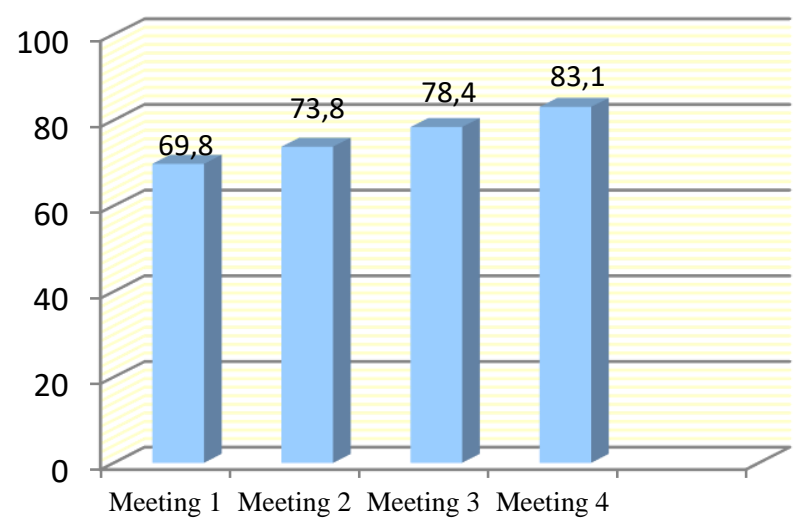

Figure 2. The Average Percentage of Students' Activities in Each Meeting

Figure 2 shows the average percentage of students' activity in the experimental class at each meeting. Based on the graph, the average percentage value of students' activity at each meeting has always increased with an average of $4.4 \%$. The average percentage increases indicated an increase due to the internalization of religious values using the Argument-Driven Inquiry learning model.

Based on the data analysis, the lowest student activity occurred at the first meeting but then increased until the fourth meeting. Students' activity at the first meeting was lower because they were confused since it was their first time applying the model. Many students asked questions during the first meeting; then, the teacher explained the Argument-Driven Inquiry learning model applied with religious values.

The following is the average percentage of students' activity at each meeting.

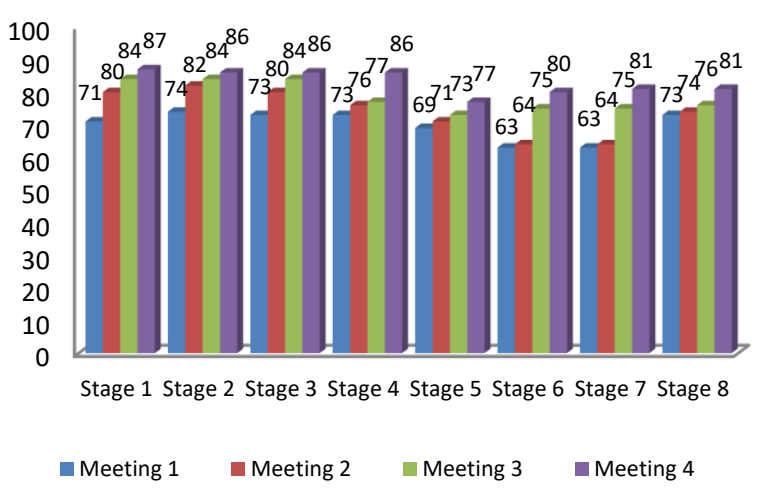

Figure 3. Graph of the Average Percentage of Student Activities in the Argument-driven Inquiry Model Stage for Each Meeting

Figure 3 shows the average percentage of students' activity during applying the Argument-Driven Inquiry learning model at each meeting. Based on the observations' results, the first meeting to the fourth meeting at all stages continued to increase. The highest students' activity occurred at the fourth meeting, namely at the task identification stage, with a percentage of $87 \%$ (excellent category). The lowest students' activity occurred at the report review stage and the report revision process with a percentage 
of $63 \%$ (moderate category). A more detailed explanation can be seen in the description below.

The pretest and posttest mean scores between the experimental and control classes are presented in Figure 4.

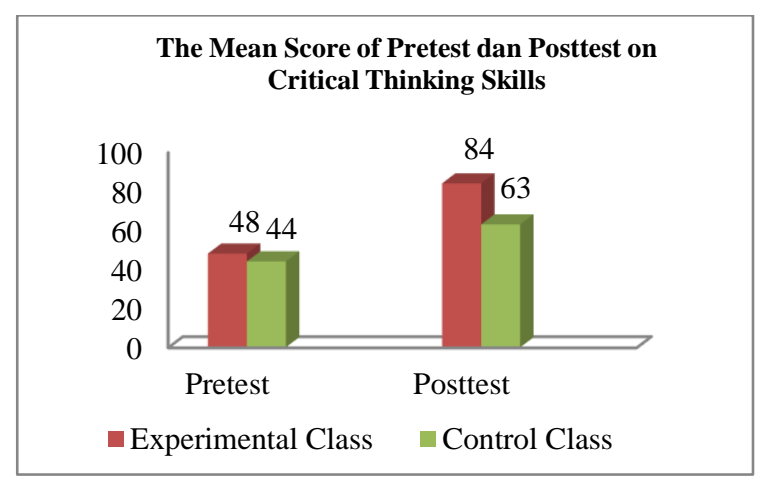

Figure 4. The pretest and Posttest Mean Scores Between the Experimental Class and the Control Class

Figure 4 shows the average results of the pretest and posttest scores of students' critical thinking skills in the experimental class and the control class in general. The experimental class was higher than the control class but the difference between the two was not too far away. This result showed that the sudents' initial abilities were similar.

The average posttest score in the experimental class and control class increased compared to the pretest value. However, the average posttest score in the experimental class was higher than the control class. This difference occurred because, in the experimental class, students received treatment from the researcher to internalize religious values using the Argument-Driven Inquiry learning model.

One factor that causes the same initial knowledge between the experimental class and the control class was that the two classes did not know the material to be studied. This phenomenon is also explained by Lipianto, who states that initial knowledge is crucial because students often experience difficulty understanding certain knowledge (Lipianto et al., 2013; Sari et al., 2012). One of the reasons is because the new knowledge does not have a relationship with previous knowledge. In this case, initial knowledge becomes the main requirement and becomes very important for students to have.

The difference in students' critical thinking skills in the experimental class and the control class can also be seen from the gain index. In this research, the $\mathrm{N}$-gain used had been normalized so that the Ngain value obtained did not exceed score 1 . Figure 5 displays the average obtained Ngain values.

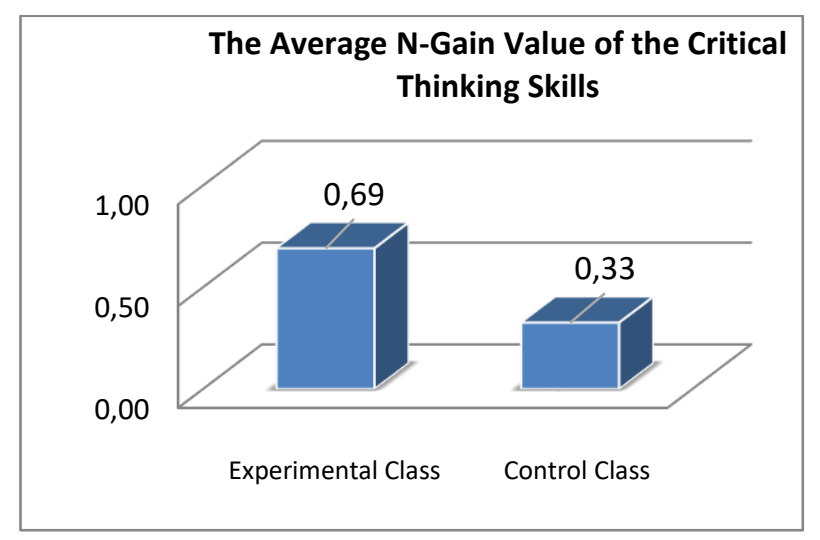

Figure 5. The Obtained N-gain Value of the Experiment Class and Control Class

Figure 5 shows that the experimental class and control class's average $\mathrm{N}$-gain values were in the moderate category. However, the average N-Gain value in the experimental class was higher than the control class. These results indicate that students' critical thinking skills in the experimental class were better than in the control class. The difference might be caused by the internalization of religious values using the Argument-Driven Inquiry learning model.

Based on the analysis, there was an increase in the experimental and control classes' critical thinking skills. However, the highest increase was in the experimental class because the 
experimental class got treatments to internalize religious values by using the Argument-Driven Inquiry learning model. The Argument-Driven Inquiry learning model is one of the learning models related to argumentation skills. This argumentation skill is also related to critical thinking skills. Following Ariyanto's statement (Ariyanto et al., 2020), critical thinking skills can be improved by developing the ability to argue since argumentation is the main thing that underlies students in learning to think, act, and communicate critically. The prerequisite tests in the experimental class and the control class are described in table 1.

Table 1. General Normality and Homogeneity Test Results

\begin{tabular}{|c|c|c|c|c|c|}
\hline \multirow{2}{*}{ Data } & \multirow{2}{*}{ Classes } & \multicolumn{2}{|c|}{ Normality test } & \multicolumn{2}{|c|}{ Homogeneity } \\
\hline & & Sig. & Result & Sig. & Result \\
\hline \multirow{2}{*}{ Gain } & Experimental & 0.028 & Abnormal & \multirow{2}{*}{0.655} & \multirow{2}{*}{ Homogeneous } \\
\hline & Control & 0.200 & Normal & & \\
\hline
\end{tabular}

Table 1 presents the results of the normality test and the homogeneity test of the $\mathrm{N}$-Gain data. The experimental class data were not normally distributed because the significant value was 0.028 , smaller than 0.05 . The data of the control class was normally distributed because the significant value was 0.200 , greater than 0.05. The results of the N-Gain data homogeneity test showed that the data were homogeneous because of the sig. 0.655 was greater than 0.05 . Based on the results of the prerequisite tests, the data was not normally distributed and homogeneous. Therefore, the test performed on the N-Gain data was the nonparametric Mann Whitney Test. The results are presented in Table 2.

Table 2. Statistical Calculation Results

\begin{tabular}{cccc}
\hline Data & $\begin{array}{c}\text { Difference } \\
\text { Test }\end{array}$ & Sig. & Result \\
\hline N-Gain & $\begin{array}{c}\text { Mann } \\
\text { Whitney }\end{array}$ & 0,000 & $\begin{array}{c}\text { Significant } \\
\text { Differences }\end{array}$ \\
\hline
\end{tabular}

Table 2 shows the N-Gain test result. The significance value was 0,000 , which means that $\mathrm{H}_{a}$ was accepted and $\mathrm{H}_{0}$ was rejected. Based on these data, it can be concluded that there was a significant difference in students' learning outcomes between the experimental class and the control class. This difference can be seen in Figure 3, which shows that the average posttest score of the experimental class was different from the average posttest score of the control class. Figure 4 shows the $\mathrm{N}$-Gain average of the experimental class where the difference was too far from the average $\mathrm{N}-$ Gain of the class control. The results indicated that the Argument-Driven Inquiry learning model was effective in increasing students' critical thinking skills.

Based on the results of the analysis, it can be seen that the learning process improved students' critical thinking skills. The experimental class that internalized religious values using the Argument-Driven Inquiry model increased its critical thinking skills higher than the control class. It was possible because, during the learning process, the students played an active role in the investigation while the teacher acted as a moderator and supervisor. Therefore, the students obtained knowledge based on the investigations they criticized themselves based on claims, evidence, and rationale. Those aspects were correlated with religious values sourced from Quran and Hadith. 
Biosfer, 11 (2) (2020) 139 - 150

Yeyen Siti Fitriani, Anda Juanda, Evi Roviati

The results are consistent with research conducted by (Demircioglu \& Ucar, 2015), which states that the Argument-Driven Inquiry learning model can improve students' critical thinking skills because they were allowed to design their research and find their research results. Thus, students will be involved a lot in scientific argumentation that will support the strengthening of their critical thinking skills. Hasnunidah (Hasnunidah, 2013). argumentative inquiry-based learning is appropriate for providing learning experiences to students in practicing their scientific argumentation skills because students will be required to construct their explanations and contribute their ideas.

The analysis results are also in line with the research conducted by Ajwar (Ajwar et al., 2015; Wulanningsih et al., 2012) that there are differences in the achievement of critical thinking skills between students who learn using the ADI learning model and the conventional model. In other words, the ArgumentDriven Inquiry learning model is very effective in the learning process to improve students' critical thinking skills because it has many advantages. Student responses toward the internalization of religious values using the Argument-Driven Inquiry learning model were investigated using questionnaires. The questionnaires were filled according to their circumstances, experiences, and opinions. The questionnaires were filled at the end of learning via Google Form.

The statements of the questionnaires were developed based on three dimensions. First, Receiving, namely, students' acceptance of the given learning model. Second, Responding (attitude to respond), namely the students' response to the given learning model. Third, Valuing (an attitude that assumes what is done is based on value), namely the given learning evaluations. The results of the analysis of the questionnaires are presented in Figure 5.

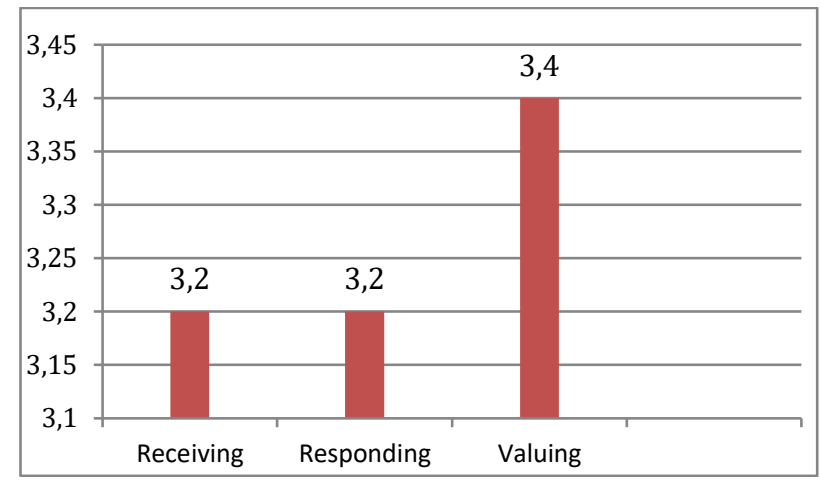

Figure 6. The Results of Questionnaire Per Dimension

Figure 6 shows the average results of the questionnaire in each learning dimension. Based on the questionnaire analysis results, the three dimensions' highest average value was the Valuing dimension. In contrast, the lowest average value was the Receiving and Responding dimensions with the same average value. The results showed that the student evaluations' results were excellent and high. The following is a diagram of the experimental class students' questionnaire responses.

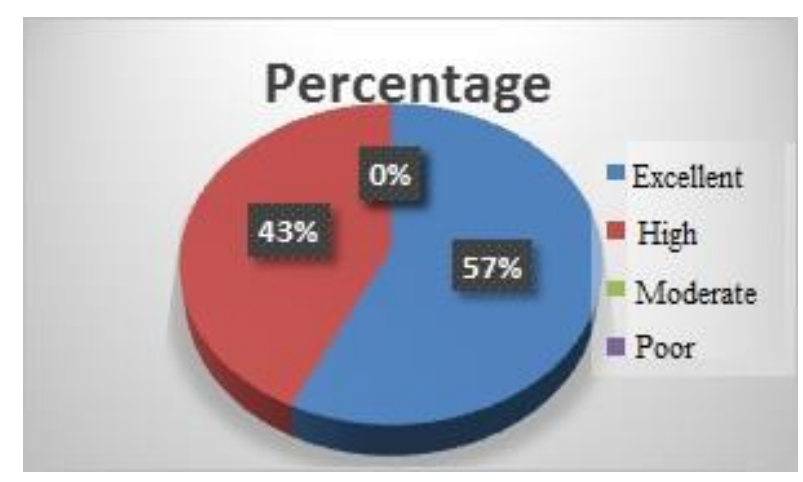

Figure 7. Experimental Class Students' Responses

Figure 6 shows a diagram of students' questionnaire responses percentage toward the internalization of religious values using the Argument-Driven Inquiry 
learning model. Based on the diagram, 57\% of students gave excellent responses, and $43 \%$ gave high responses.

Based on the analysis results, biology learning by internalizing religious values using the Argument-Driven Inquiry learning model provided a new learning process for students in understanding reproductive system material. The internalization process of religious values in reproductive system material can increase students' knowledge, both cognitive and affective. The results of students' activity and learning processes can improve their critical thinking skills. Besides, it also produced positive excellent students' responses.

This statement was proven by the data obtained, which indicated that the internalization of religious values using the Argument-Driven Inquiry learning model on reproductive system material obtained a good response from students in the experimental class. Good students' response to the integration of religious values using the Argument-Driven Inquiry learning model in biology learning to improve critical thinking skills can be a solution so that students can understand the concept as a whole material content and the religious perspective.

The results showed that the internalization of religious values using the Argument-Driven Inquiry learning model in biology learning could be used as an alternative that can support effective and fun teaching and learning activities to achieve learning objectives. Teachers' success in transferring knowledge to students depends on the learning method applied and the teaching materials to absorb the knowledge transferred by the teacher. Internalization of religious values using the Argument-Driven Inquiry learning model in biology learning is expected to develop students' intellectual intelligence, which then impacts students' awareness. The students are not only provided with learning materials but also accompanied by religious attitudes and behaviors.

\section{CONCLUSIONS AND SUGGESTIONS}

Based on the research results, it can be concluded that biology learning by applying the internalization of religious values using the Argument-Driven Inquiry model can be essential to apply because it can improve students' learning activities and critical thinking skills. Applying this research to other materials and maximizing learning time in improving critical thinking skills is suggested.

\section{REFERENCE}

Abdurrohman, A., \& Djuniadi, D. (2016). Analysis of Mathematical Critical Thinking Ability through Station Learning Approach Metaphorical Thinking. Unnes Journal of Mathematics Education Research, 5 (2), 90-97.

Aditya, DY (2016). The Effect of the Application of Recitation Learning Methods on Students' Mathematics Learning Outcomes. SAP (Composition of Educational Articles), 1 (2).

Adnyana, GP (2012). Student Concept in Learning Cycle Model. Journal of Education and Teaching, 3, 201209.

Adnyani, IW, Pujani, NM, \& Juniartina, PP (2018). The Influence of the 7E Learning Cycle Model on Students' Critical Thinking Skills. Indonesian Journal of Education and Learning Science (JPPSI), 1 (2), 56-67.

Ajwar, M., Prayitno, BA, \& Sunarno, W. (2015). The Effect of Guided Inquiry Learning and Modified Free Inquiry on Learning Achievement in Critical 
Biosfer, 11 (2) (2020) 139 - 150

Yeyen Siti Fitriani, Anda Juanda, Evi Roviati

Thinking and Discipline of Class $\mathrm{X}$ MIA Students of SMA Negeri 8 Surakarta Academic Year 2014/2015. INKUIRI: Journal of Science Education, 4 (3), 127-135.

Ariyanto, SR, Lestari, IWP, Hasanah, SU, Rahmah, L., \& Purwanto, DV (2020). Problem Based Learning and Argumentation as a Solution in Improving the Critical Thinking Ability of Vocational School Students. Journal of Education: Journal of Research Results and Literature Studies in the Field of Education, Teaching and Learning, 6 (2), 197-205.

Asrori, M. (2013). Definition, objectives and scope of learning strategies. Madrasah: Journal of Education and Basic Learning, 5 (2), 26.

Azhar, K., \& Sa'idah, I. (2017). An analysis study of the Akidah Akhlak teacher's efforts in developing the potential moral values of students in MI in Demak Regency. Al-TA'DIB: Journal of Educational Studies, 10 (2).

Aziz, B. (2012). The mind map learning method's influence on student learning outcomes on the subject matter of vibrations and waves in class VIII SMP Negeri 12 Binjai. Journal of Unimed Physics Education, 1 (1), 51-56.

Bahri, S. (2015). Implementation of character education in overcoming moral crises in schools. Ta'allum: Journal of Islamic Education, 3 (1), 57-76.

Wake up, SY (2016). Knowledge Development for Children with Disabilities through Physical Education, Sports and Outbound.
Journal of Physical Education, Health and Recreation, 1 (1), 70-77.

Brata, IB, \& Sudirga, IK (2019). Megeguritan: Character Education Media for Young Generation in Facing Global Cultural Flow (Case Study in Pakraman Village, Bresela Payangan, Gianyar). Mudra Journal of Cultural Arts, 34 (2), 230-238.

Cahyono, H. (2016). Character Education: Value Education Strategies in Forming Religious Character. Ri'ayah: Journal of Social and Religious Affairs, 1 (02), 230-240.

Demircioglu, T., \& Ucar, S. (2015). Investigating the effect of argumentdriven inquiry in laboratory instruction. Educational Sciences: Theory \& Practice, 15 (1).

Dewi, FR, Azmi, N., \& Gloria, RY (2015). The application of IMTAQ-based biology learning on the concept of ecosystems to improve student learning outcomes in Class X SMA Negeri 1 Jamblang. Scientiae Educatia: Journal of Science Education, 5 (2). Fauziah, U. (2018).

Integrated Problem Based Learning of Religious Character in Human Reproductive System Material. Journal of Informatics and Science Education, 7 (1), 91-106.

Ginanjar, MH (2017). Balance the role of parents in shaping children's character. Islamic Education: Journal of Islamic Education, 2 (03).

Haeruman, LD, Rahayu, W., \& Ambarwati, L. (2017). The effect of the discovery learning model on the improvement of mathematical critical thinking skills and self- 
confidence in terms of the initial mathematical abilities of high school students in East Bogor. JPPM (Journal of Mathematics Research and Learning), 10 (2).

Hanif, H., Ibrohim, I., \& Rohman, F. (2016). Development of biology learning tools for plantae material based on guided inquiry integrated with Islamic values to improve the conceptual understanding of high school students. Journal of Education: Theory, Research, and Development, 1 (11), 2163-2171.

Hasnunidah, N. (2013). Biology learning with argument-driven inquiry strategy and argumentation skills of students. Journal of Biology Education, State University of Malang, 5 (1), 1-29.

Hidayat, W. (2017). Adversity quotient and high school students' mathematical creative reasoning in argumentdriven inquiry learning on derivative function material. KALAMATIKA: Journal of Mathematics Education, 2 (1), 1528.

Husamah, H., Fatmawati, D., \& Setyawan, D. (2017). OIDDE learning model in environmental knowledge courses to improve critical thinking skills of prospective biology teacher students. Journal of Bioeducatics, 5 (2), 73-85.

Husna Nafila, N., Azmi, N., Muspiroh, N., Kunci, K., Application,:, Biology, P., Imtaq, B., \& Berfikir, K. (2016). Application of Faith and Faith-Based Biology Learning (Imtaq) on the Concept of Human Reproduction Systems to Improve Critical Thinking Skills of Class Xi Senior
High School 1 Ciwaringin Students. Scientiae Educatia: Journal of Science and Science Education, 5 (2), 136-143.

Irhandayaningsih, A. (2013). Character Education in Higher Education: Responding to Moral Dependence among the Young Generation. HUMANIKA, 17 (1).

Juraini, F., Habibah, S., \& Mislinawati, M. (2018). Moral Development for Students in the Learning Process at SD Negeri Unggul Lampeneurut Aceh Besar. Scientific Journal of Primary School Teacher Education Students, 3 (2).

Kautsar, A., \& Edi, J. (2017). Religious Character Education, Discipline and Talent through Improving the Quality of School Infrastructure. JMKSP (Journal of Management, Leadership, and Education Supervision), 2 (2), 259-277.

Khotimah, K. (2016). Management Model for Religious Character Education at SDIT Qurrota A'yun Ponorogo. Muslim Heritage, 1 (2), 371-388.

Lestari, D., ES, SM, \& Susanti, R. (2016). Development of Blended Learning Tools for Human Nervous System to Improve Critical Thinking Skills. Journal of Innovative Science Education, 5 (1), 83-93.

Lipianto, D., Budiarto, MT, Mathematics, J., Surabaya, UN, Mathematics, J., \& Surabaya, UN (2013). Analysis of students' errors in solving questions related to squares and rectangles based on the solo plus taxonomy in class vii. MATHEdunesa Scientific Journal of Mathematics Education, 2 (1). 
Biosfer, 11 (2) (2020) 139 - 150

Yeyen Siti Fitriani, Anda Juanda, Evi Roviati

Marhamah, OS, Nurlaelah, I., \& Setiawati, I. (2017). The application of the argument-driven inquiry (ADI) model in improving students' argumentative abilities on the concept of environmental pollution in class $\mathrm{X}$ SMA Negeri 1 Ciawigebang. Quagga: Journal of Education and Biology, 9 (02), 3945.

Mumin, UA (2018). Tolerance Education Perspective of Islamic Religious Education (Analysis of the Content of Learning Approaches in Schools). al-Afkar, Journal For Islamic Studies, 1 (2, July), 15-26.

Muspiroh, N. (2016). Integration of Islamic values in science learning (Islamic education perspective). Journal of Islamic Education UIN Sunan Gunung Djati, 28 (3), 484-498.

Nafi'ah, I., \& Prasetyo, APB (2015). Analysis of students' critical thinking habits when learning science curriculum 2013 has a scientific approach. Journal of Biology Education, 4 (1).

Nisa, K., Ashari, A., \& Kurniawan, ES (2019). Development of Physics Dictate Based on Problem Based Learning to Improve Students' Critical Thinking Ability. Radiation: Periodic Journal of Physics Education, 12 (1), 20-27.

Novrizawati, F., Suyatna, A., \& Fadiawati, N. (2017). The Effectiveness of the Application of the Trapi Learning Model to Foster Critical Thinking Skills. Journal of Learning Physics, 5 (1).

Okmarisa, H., Darmana, A., \& Suyanti, RD (2016). The implementation of chemistry teaching materials is integrated with spiritual values with a collaborative oriented problem based learning (pbl) learning model to improve student learning outcomes. Journal of Chemical Education, 8 (2), 130-135.

Rachmayanie, R. (2017). Pre-Marital Sex as a Problem of Middle School Youth. PROCEEDING SEMINAR AND NATIONAL COUNSELING AND COUNSELING WORKSHOP 2017, 1, 248-263.

Romdoni, LN, \& Malihah, E. (2020). Building Santri Character Education through the Five Spirit Islamic Boarding Schools. Journal of Islamic Religious Education Al-Thariqah, 5 (2), 13-22.

Rosyad, AM (2019). The Implementation of Multiculturalism Values through Learning of Islamic Religion Education (The Implementation of Multiculturalism Values Through Learning of Islamic Religion Education). Risâlah, Journal of Islamic Education and Studies, 5 (1, March), 1-18.

Rustaman, NY (2011). Science Education and Research in Developing HigherOrder Thinking Skills for Character Building. Proceeding Biology Education Conference: Biology, Science, Environmental, and Learning, 8 (1), 15-34.

Saat, S. (2015). Determinant Factors in Education (Study of Meaning and Position in Education). Al-TA'DIB: Journal of Educational Studies, 8 (2), 1-17.

Sari, EK, Ulfiana, E., \& Rachmawati, PD (2012). The effect of dental 
brushing health education using the snake and ladder simulation game method on changes in knowledge, attitudes, and the application of brushing teeth for school-age children in SD Paron Ngawi. Indonesian Journal of Community Health Nursing, 1 (1).

Setiardi, D., \& Mubarok, H. (2017). Family as a source of character education for children. Tarbawi: Journal of Islamic Education, 14 (2).

Shawmi, AN (2015). Life Skill Education in Learning Science in SD / MI. Skilled: Journal of Education and Basic Learning, 2 (2), 240-252.

Sofanudin, A. (2015). Internalization of national character values through Islamic religious education subjects at ex-RSBI High School in Tegal. Journal of SMART (Study of Society, Religion and Tradition), 1 (2).

Syafe'i, I. (2017). Islamic boarding schools: Character building educational institutions. Al-Tadzkiyyah: Journal of Islamic Education, 8 (1), 61-82.

Wahyuni, A., Tias, AAW, \& Sani, B. (2013). The role of ethnomathematics in building the character of the nation. Papers of the National Seminar on Mathematics and Mathematics Education, Proceedings, Department of Mathematics Education, Faculty of Mathematics and Natural Sciences, Yogyakarta: UNY.

Widyaningsih, TS, Zamroni, Z., \& Zuchdi, D. (2014). Internalization and actualization of character values in junior high school students in a phenomenological perspective. Journal of Educational
Development: Foundations and Applications, 2 (2).

Wulanningsih, S., Prayitno, BA, \& Probosar, R. (2012). The effect of guided inquiry learning models on science process skills in terms of the academic abilities of students of SMA Negeri 5 Surakarta. Journal of Biological Education, 4 (2), 33-43.

Zubaidah, S. (2010). Critical Thinking: Higher-Order Thinking Skills That Can Be Developed Through Science Learning. National Seminar Paper on Science with the theme of Optimizing Science to Empower Humans. Postgraduate Unisa, 16. 